\title{
Can the early stage copepoda (Copepodites and Naupliies) abundance play important role on the fatty acid composition of Sagitta setosa (Chaetognatha) in the Southeastern Black Sea?
}

\section{Güneydoğu Karadeniz'de erken aşamadaki kopepod (Kopepoditler ve Naupliler) bolluğu Sagitta setosa (Chaetognatha) yağ asiti kompozisyonu üzerinde önemli rol oynayabilir mi?}

\author{
Nurgül Şen Özdemir ${ }^{*}$ • Ali Muzaffer Feyzioğlü • Fatma Caf ${ }^{3}$ • İlknur Yıldız

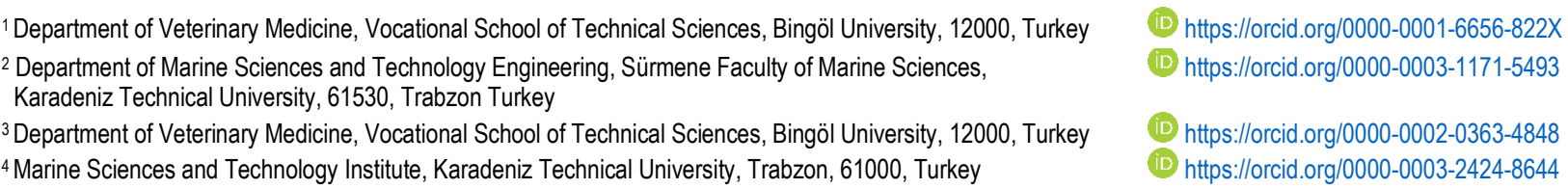

Şen Özdemir, N., Feyzioğlu A.M., Caf, F. \& Yıldı, İ. (2020). Can the early stage copepoda (Copepodites and Naupliies) abundance play important role on the fatty acid composition of Sagitta setosa (Chaetognatha) in the Southeastern Black Sea? Ege Journal of Fisheries and Aquatic Sciences, 37(4), 335-342. DOI: 10.12714/egejfas.37.4.03

Abstract: In this study, the relationship between the fatty acid composition, abundance of carnivore Sagitta setosa (S. setosa) and total copepod abundance (copepodites and nauplii) which are the main diets of $S$. setosa was investigated. Sampling was conducted monthly during a year. During the sampling period, S. setosa and the total the copepod abundance showed a parallel distribution until November. Average total lipid was at the highest with $3 \%$ in spring and autumn, while the lowest was $2 \%$ in winter and summer. While DHA/EPA ratio (2.23) as carnivory index in S. setosa and the total copepod (copepodites and nauplii) abundance (1375 ind $/ \mathrm{m}^{3}$ ) were at the highest in winter, but another carnivory index, 18:1 $\mathrm{\omega g} / 18: 1 \mathrm{\omega} 7$ ratio did not show a parallel increase with copepod abundance. However, 18:1w9 which increases the carnivory index, is among the main fatty acids in $S$. setosa. This might be indicated that $S$. setosa does not related to predation on the copepods, but it shows that feeding in a carnivorous style. Additionally, the herbivory index $\sum n-3 / \sum n-6$ ratio was detected in spring and autumn at the highest level. Consequently, although there is no direct effect between the copepod abundance and $S$. setosa fatty acids, it is possible an indirect effect.

Keywords: Carnivory index, fatty acids, Sagitta setosa, Southeastern Black Sea

Öz: Bu calışmada karnivor bir tür olan Sagitta setosa'nın yağ asiti kompozisyonu ve bolluğu ile üzerinden yoğun bir şekilde beslendigi kopepodların (kopepoditler ve kopepot nauplileri) bolluğu arasındaki ilişki incelenmistir. Örneklemeler bir yıl boyunca aylık periyotlarda yapılmıştır. Örnekleme dönemi boyunca S. setosa ve toplam copepod bolluğu, kasım ayına kadar parallel bir dağılım göstermiştir. Ortalama toplam lipit miktarı \%3 ile en yüksek ilkbahar ve sonbahar, en düşük ise \%2 ile kış ve yaz aylarında belirlenmiștir. S. setosa'da karnivor indeksi olarak DHA/EPA oranı $(2,23)$ ve kopepod bolluğu $\left(1375\right.$ birey $\left./ \mathrm{m}^{3}\right)$ en yüksek değerlerini kı̧ döneminde almışlardır. Bu dönemdeki yüksek kopepod bolluğunun $S$. setosa'daki karnivor indeksi yağ asitlerini artırmaya katkı sagladığı söylenebilir. Fakat diğer bir karnivor indeksi olan 18:1 $199 / 18: 1 \omega 7$ oranı kopepod bolluğu ile papalel bir artış gostermemiştir. Ancak, karnivor indeksini artıran 18:1w9 un S. Setosa'daki temel yağ asitleri arasında olması, S. setosa'nın her zaman kopepodlar üzerinden bir predasyon sergilemese de karnivor beslendiğine kanıt olarak gösterilebilir. Bunun yanında, herbivor indeksi olan $\sum \omega 3 / \sum \omega 6$ oranı en yüksek ilkbaharda ve sonabaharda belirlenmiştir. Sonuç olarak, kopepod bolluğu ile S. setosa'nın yağ asitteri arasında direkt bir etki olmasa da indirekt bir etkinin varlığından bahsedilebilir.

Anahtar kelimeler: Karnivor indeksi, yağ asitleri, Sagitta setosa, Güneydoğu Karadeniz

\section{INTRODUCTION}

Chaetognaths are important zooplankton predators in marine environments (Reeve, 1980; Feigenbaum and Maris, 1984; Baier and Purcell, 1997). Their main diet consists of copepods (Feigenbaum and Maris, 1984; Feigenbaum, 1991; Duró and Saiz, 2000). On the other hand, they are noteworthily a link between the phytoplankton and many fish species, especially including commercially important fish species (Vinogradov et al., 1992; Kovalev et al., 1998).
Sagitta setosa ( $S$. setosa) which is a chaetognath species, is commonly found in the Black Sea Sea (Zenkevitch, 1963; Vinogradov et al., 1990; 1992; Niermann and Greve, 1997). It accumulates more along rim current than shelf areas and in the central gyres of the Black Sea (Niermann et al., 1997). The most crucial factors affecting the growth of $S$. setosa in the Black Sea are temperature and food supply. (Beşiktepe and Ünsal, 2000; Yıldız and 
Feyzioğlu, 2014). Additionally, the abundance of S. setosa was affected by the existence of appropriate food intensity during the previous month (about a month ago). Therefore, in this study, the purpose was to determine the relation between the seasonal fatty acid composition of $S$. setosa, which is one of the important zooplankton predators in the Black Sea ecosystem, and the seasonal abundance distribution of copepodites and copepod nauplii, which are the main diet of $S$. setosa. It was investigated in a different perspective on which periods/which fatty acids of $S$. setosa have a high level and whether or not there is a relationship between $S$. setosa fatty acids and copepod (copepodites and nauplii) abundance. Because, fatty acids (FA) are among the most important molecules transferred from plant to animal in aquatic food webs. Certain classes of FA, such as the omega3 ( $\omega 3 ; n-3)$, highly unsaturated fatty acids (HUFA) which are available in limited quantities and very important for herbivore zooplankton are transferred from phytoplanktonic organisms to upper trophic levels (Müller-Navarra, 1995; Müler-Navarra et al., 2000; Ravet et al., 2003). FA have three characteristics and storage patterns. These special features make them useful tracers of diets and aquatic food webs. First, organisms can establish biosynthesize, modify chain length, and introduce double bonds in FA. However, they are subject to biochemical limitations in these processes depending on the phylogenetic group and even species (Cook, 1996). Second, unlike other dietary nutrients (e.g., proteins and carbohydrates) which digestion is completely degraded, FA are released from the digestive amounts of digested lipid molecules, but are generally not deformed and taken up in basic forms by tissues. The important consequences of these restrictions within plants, bacteria, and animals, and the uptake of intact FA by consumer tissues, is that individual isomers as well as "families" of FA bioaccumulate through food chains, and they can be traced back to specific food web origins. Third, unlike most other nutrients, fat is stored as reservoirs in animal bodies. These often-substantial stores can later be mobilized to provide fuel for short or long-term energy demands (Pond, 1998). Therefore, FA accumulate over time and represent an integration of dietary intake over days, weeks, or months, depending on the organism and its energy intake and storage rates. In addition, it is important to know FA composition of the zooplankton which by taxonomic affiliation, changed by diet and modified by starvations or temperature (Arts et al., 2009).

\section{MATERIALS AND METHODS}

\section{Location of expedition and sampling}

R/V YAKAMOZ research boat, which belonged to Faculty of Marine Science, KTU was used in samplings. The zooplankton samples were collected monthly from the Southeastern Black Sea Sürmene Bay between March 2012February 2013. The station was 3 sea miles far $\left(40^{\circ} 57^{\prime} 12^{\prime \prime} \mathrm{N}\right.$ - $40^{\circ} 09^{\prime} 30^{\prime \prime} E$ ) from the coast, and has a depth of 400 meters. The Exgolabur 7 GPS was used in determining of the station. The zooplankton samples were collected vertically with Hansen plankton net having $110 \mathrm{~cm}$ mouth diameter and 200 $\mu \mathrm{m}$ mesh widthr from $130 \mathrm{~m}$ depth to the surface in determination of the abundance and fatty acid composition (Harris et al., 2000). A conductivity- temperature-depthoxygen CTD profiler (CTD, General Oceanic Idranaut 316) was used in determination of temperature values.

\section{Determination of abundance for the zooplankton species}

The zooplankton samples were preserved in a $4 \%$ formaldehyde seawater solution buffered with sodium borate. Countings were done under stereomicroscopes (Olympus $\mathrm{BH} 2$ and Nikon) using $4 \times$ and $10 \times$ objectives and a BogorovRass counting chamber. Quantitative analyses of species were performed by using $3 \mathrm{ml}$ subsamples. Countings were repeated on 4 subsamples (Harris et al., 2000). The copepods (copepodites, copepod nauplii) were identified to species or genus level (Mauchline et al., 1998; Johnson and Allen, 2005). The zooplankton abundance was expressed as the number of the individuals in $\mathrm{m}^{3}$ (ind $/ \mathrm{m}^{3}$ ). Zooplankton abundance was performed with monthly intervals, copepodites and nauplii of 5 species from copepoda were detected (Calanus euxinus, Pseudocalanus elongatus, Acartia clausi, Paracalanus parvus, Centropages ponticus): 1 species of cyclopoid copepod was detected (Oithona similis): and 1 species was detected from Chaetognatha (S. setosa).

\section{Total lipid and fatty acid analysis}

Lipids were quantitatively extracted from the samples using chloroform/methanol (2:1) (Folch et al., 1957). To determine the fatty acids methyl esters (FAME) is used $2 \mathrm{ml}$ chloroform and $1 \mathrm{ml} 0.21 \mathrm{~N} \mathrm{NaOH}$ in methanol solution were used. Then, $0.5 \mathrm{~N}$ acetic acid solution was added. Lower phase was evaporated and $2 \mathrm{ml}$ hexane was added on the lipid and the sample was transferred to a vial (Kates, 1986). The FAME were detected by Shimadzu GC-17 gas chromatograph (GC). Capillary columns with a length of $25 \mathrm{~m}$, inner diameter of $0.25 \mu \mathrm{m}$, and with a thickness of $25 \mu$ (Permabond) were used (Macherey-Nagel). Column temperature was set to $120-220^{\circ} \mathrm{C}$, with the increment of 5 ${ }^{\circ} \mathrm{C} / \mathrm{min}$ until $200{ }^{\circ} \mathrm{C}$ and $4{ }^{\circ} \mathrm{C} / \mathrm{min}$ to $220^{\circ} \mathrm{C}$. The column was kept for $8 \mathrm{~min}$ at $220^{\circ} \mathrm{C}$ and the total time was determined as 35 minutes. Injection temperature is set to $240{ }^{\circ} \mathrm{C}$ and detector temperature to $280{ }^{\circ} \mathrm{C}$. Nitrogen was used as the carrier gas.

\section{Statistical analysis}

STATISTICA 8.0 was used in statistical analysis. The datas were analyzed using analysis of variance (one way ANOVA) method and comparisons among averages were carried out by using Tukey Test. Tukey test created by Post- 
hoc, homogenous groups $(p<0.05)$. In definitions of the statistical differences, the Spearman Rank Correlation was applied $(p<0.05)$.

\section{RESULTS AND DISCUSSION}

Fatty acids have often been used to track energy transfer, as well as to study predator-prey relationships (Falk-Peterson et al., 1990: 2000; Litzow et al., 2006). In this study, the relation between $S$. setosa abundance and fatty acids and the total copepod abundance was examined in the sampling period to reveal the prey-predator relation. A constant increase was observed from Spring to Winter (Spring: 268 ind $/ \mathrm{m}^{3}$, Summer: $398 \mathrm{ind} / \mathrm{m}^{3}$, Autumn: $814 \mathrm{ind} / \mathrm{m}^{3}$, Winter: $1375 \mathrm{ind} / \mathrm{m}^{3}$ ) in the total copepod (copepod nauplii and copepodite) abundance. While copepod nauplii reached the highest abundance in February $\left(457 \mathrm{ind} / \mathrm{m}^{3}\right.$ ), copepodites reached the highest abundance in January $\left(1668 \mathrm{ind} / \mathrm{m}^{3}\right)$. Although S. setosa and the total copepod abundance showed a parallel distribution until November, the total copepod abundance increased $S$. setosa abundance decreased when compared to the previous month in November and February. In December, the total copepod abundance decreased $S$. setosa abundance increased compared to the previous month. (Figure 1). This situation is common only in late summer and autumn." (Øresland, 1983, 1985; Yıldı and Feyzioğlu, 2014). Breeding and growth of S. setosa accur after the copepods reached the highest abundance (Niermann et al., 1997) because, copepods are the primary food source of S. setosa (Feigenbaum, 1991). Food and temperature are major factors affecting the growth of $S$. setosa in the Black Sea (Beşiktepe and Ünsal, 2000). We determined that the average water temperature $\left({ }^{\circ} \mathrm{C}\right)$ in the 100 $\mathrm{m}$ water column was based during the sampling period. The lowest average water temperature was determined in March $\left(8^{\circ} \mathrm{C}\right)$ and the highest average water temperature was determined in August $\left(14^{\circ} \mathrm{C}\right)$ during the sampling period.

It was reported that breeding of $S$. setosa was probably most intensive from June to November (indicated by the frequency of small individuals) in 1994-1996 in the different stations by Beşiktepe and Ünsal (2000). Øresland (1987) observed small individuals of $S$. setosa, indicating intensive spawning, from July to early October in the western English Channel. Niermann and Greve (2007) observed the replacement of the entire population of $S$. setosa by a new generation in August in the Black Sea. Microscopic observation suggested that two broods were produced abundance the breeding period, as most of the adults belonging to the new generation had eggs in their gonads in June (Beşiktepe and Ünsal, 2000). In this study, too, it is observed that based on the average weight per individual of S. setosa, the biggest individuals are in May $(10 \mathrm{mg} / \mathrm{ind})$ and June ( $9 \mathrm{mg} / \mathrm{ind})$, and the smallest individuals are in November and February (2 mg/ind). S. setosa abundance and individual weights showed a parallel change in August, (Figure 2). It was found that the relationship between temperature and abundance and average individual weight of $S$. setosa was not significant $\left(r^{2}=0.5 ; r^{2}=-0.5\right.$, respectively) $(p<0.05)$. However, the relationship between the total copepod abundance and individual weight of $S$. setosa was significant $\left(r^{2}=0.8\right)(p<0.05)$.

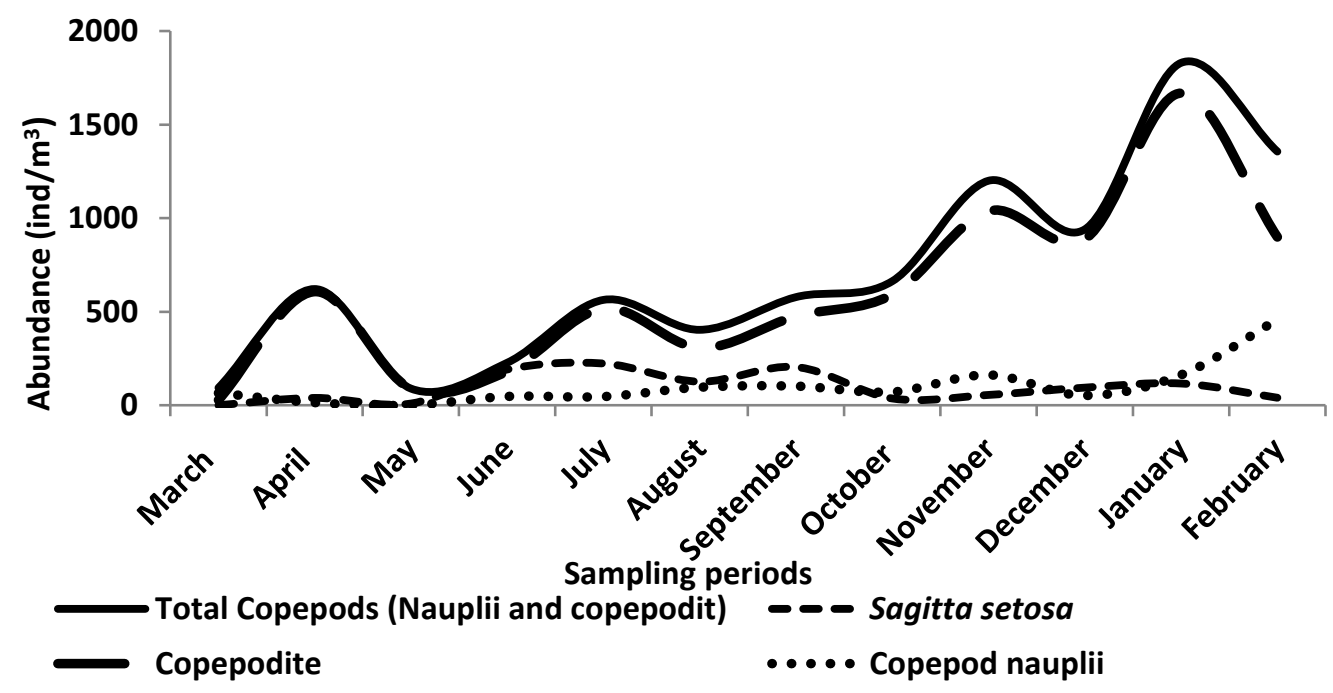

Figure 1. Abundance of the total copepods and S. setosa during the sampling period

In the study, the total lipid was at the highest in Spring and Autumn with $3 \%$, and at the lowest in winter and summer with $2 \%$ during the sampling period. The average lipid per individual was at the highest in spring $(0.21 \mathrm{mg} / \mathrm{ind})$ and in summer $(0.17 \mathrm{mg} / \mathrm{ind})$, and at the lowest in autumn $(0.16$ $\mathrm{mg} / \mathrm{ind})$ especially in winter $(0.07 \mathrm{mg} / \mathrm{ind})$. The average 
individual weight showed parallelism to $\sum$ lipid (mg/ind) level, and there is a linear relation between them $\left(R^{2}=0.9\right)$. The average individual weight was determined at the highest in spring $(6.4 \mathrm{mg})$ and in summer $(6.7 \mathrm{mg})$, and at the lowest in autumn (4.7 mg) and winter (3.2) (Figure 3). When the fact that small individuals enter the population in periods when the individual weight was low in $S$. setosa is considered, we may claim that this period continues during autumn when the onset of this period was observed. This shows that in S. setosa, there is a relation between the time-dependent change of the lipid level and the development periods. It is observed that the lipid levels are high in adulthood periods. Choe et al. (2003) found that chaetognath Parasagitta elagans lipid levels were relatively high in spring and summer and low in the fall and winter from the hyperbenthic zone of Conception Bay,
Newfoundland. Their results showed that $P$. elegans (Copepoda) had rich lipid while maturing abundance spring and summer. This increase in lipid when mature copepods increased in the spring and summer rather than when total abundance of copepods increased in the fall (Choe et al., 2003). However, it was unlike this situation in our study. And it was determined that the abundance was low in the copepod individuls at all stages in periods when total lipid was high. This made us consider that in these periods, S. setosa feed on other zooplanktonic species, which are abundant in this period, rather than copepods. Şen Özdemir (2013) reported in Southeastern Black Sea Region that the most abundant zooplankton group was the cladocerans in 2012-2013 period in June (581 ind $\left./ \mathrm{m}^{3}\right)$ and in July (1748 ind $/ \mathrm{m}^{3}: 52 \%$ of the total zooplankton).

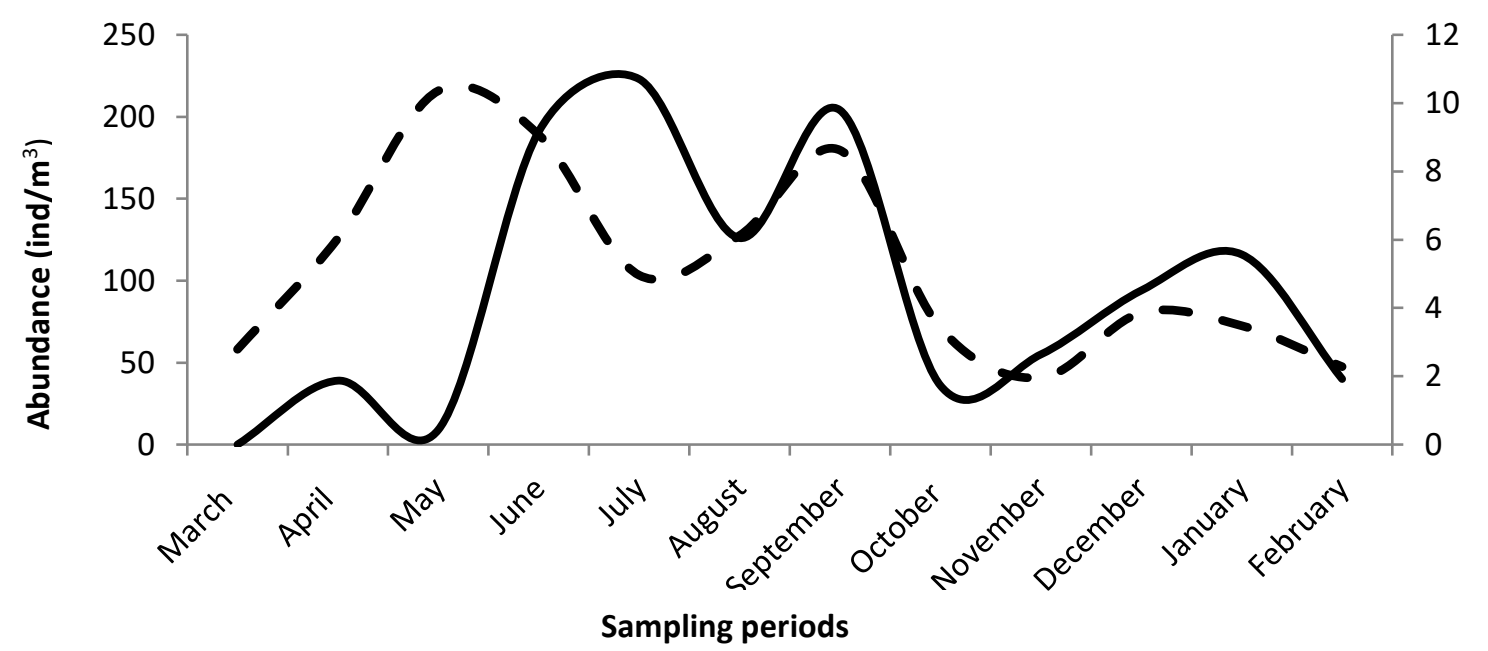

Sagitta setosa - Individual Weight of S. setosa

Figure 2. The changes in the average individual weight (mg/ind) and abundance of $S$. setosa during the sampling period

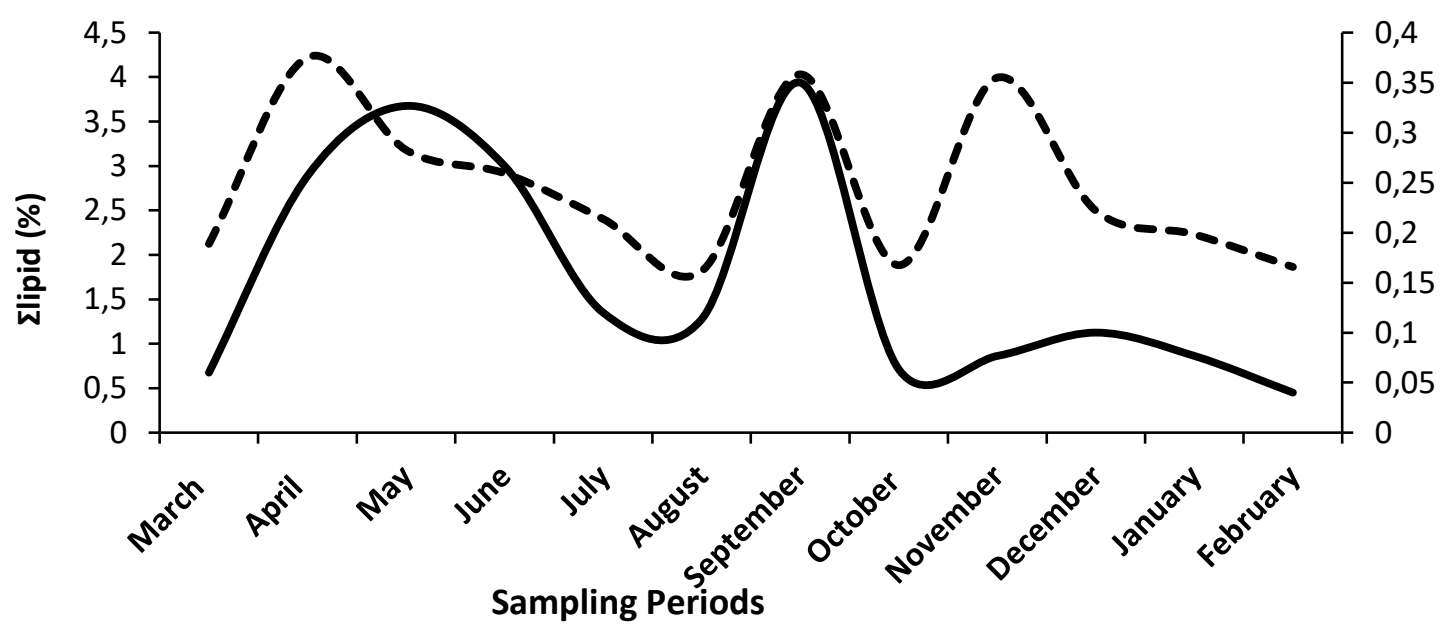

Figure 3. Changes of total lipid ( $($ lipid) (\%: mg/ind) of Sagitta setosa during the sampling period 
Beşiktepe and Ünsal (2000) observed the highest abundance in September. Similar observations were made in Crimea coastal area in the Black Sea. It was reported that in periods when $S$. setosa is abundant at the highest level, the copepods, which are their primary feed, are also abundant (Feigenbaum, 1991). Large numbers of copepods appear in June. This period of high copepod density and higher temperature is followed by the growth and maturity of $S$. setosa, suggesting that food and temperature are major factors affecting the growth of $S$. setosa in the Black Sea (Beşiktepe and Ünsal, 2000). Ünal (2002) determined that the $S$. Setosa abundance increased together with the increase in copepods in Summer and early Autumn in the coastal and open stations. A similar situation was also determined by Yıldız and Feyzioğlu (2014).

Öztürk (2002) determined the highest abundance in November in 1999, and reported that the highest values were determined in summer months in 2000-2001. It was reported in this study that the highest abundance between 1999-2001 (4.451 ind $\left./ \mathrm{m}^{2}\right)$ in 2000 July. Yıldız and Feyzioğlu (2014), reported that $S$. setosa reached its highest abundance in October in $1999\left(82.618 \mathrm{ind} / \mathrm{m}^{2}\right)$, in May in 2000 (93.768 ind $\left./ \mathrm{m}^{2}\right)$, in summer months in 2001, in August in 2002, (9.713 ind $\left./ \mathrm{m}^{2}\right)$, in June in $2005\left(3.699 \mathrm{ind} / \mathrm{m}^{2}\right)$ and in 2006, in September $\left(17.752 \mathrm{ind} / \mathrm{m}^{2}\right)$. The findings that were obtained about the $S$. setosa, which was reported to have been determined with the highest abundance level in summer, are in agreement with the data obtained by by Beşiktepe and
Ünsal (2000), Öztürk (2002) and Yıldız and Feyzioğlu (2014). However, when the changing environmental conditions in time are considered in sampling periods and according to stations, it is normal that there are several differences.

In this study, during the sampling periods, the following values were determined in $S$. setosa, which is a carnivore species: $\Sigma$ SFA $21.65 \%$, IMUFA $19.87 \%$, $\quad$ LPUFA $58.47 \%$. 18:0 is a major fatty acid in animals and some fungi, and a minor component in most plants (Rustan and Drevon, 2005). Saturated fatty acids (SFA) including 16:0, 18:0 and 14:0 are typical calanoid copepods (Prahl et al., 1984: Harvey 1987: Sargent and Falk-Peterson, 1988; Veloza et al., 2006). In this study, 18:0, 14:0 and 16:0 were among the most important SFA (Table 1). When the copepod abundance is considered along the sampling period, it is observed that 16:0, which is at the highest level in March in $S$. setosa. Therefore, it is considered that the species that might be preferred as nutrient by copepods are these, because the fatty acid composition is affected by the changes in nutrient sources and variety along the year (Morris, 1971; Ackman et al., 1974; Lee et al., 1971). Veloza et al. (2006) indicated that 16:0 was one of most abundant SFA in $A$. tonsa. Similarly, Şen Özdemir et al. (2017) 16:0 was the most abundant fatty acid in C. euxinus of the Eastern Black Sea. In this study, all the copepod species that might be preferred by $S$. setosa except for 0 . similis (Cyclopoid) are being calanoid copepods might indicate the predation of $S$. setosa over these copepod species in this intensity.

Table 1. SFA composition of Sagitta setosa during the sampling season (\% determined total FAME)

\begin{tabular}{|c|c|c|c|c|c|c|c|c|c|c|c|c|}
\hline FA & March & April & May & June & July & August & September & October & November & December & January & February \\
\hline $14: 0$ & - & $1.21 \pm 0.06^{b}$ & $1.73 \pm 0.35^{b}$ & $2.62 \pm 0.09 \mathrm{ab}$ & $2.75 \pm 0.10^{\mathrm{ab}}$ & $1.86 \pm 0.08^{b}$ & $3.01 \pm 0.99 \mathrm{ab}$ & - & $4.52 \pm 2.51^{a}$ & $1.75 \pm 0.03^{c}$ & $1.34 \pm 0.08^{c}$ & $1.00 \pm 0.21 \mathrm{e}$ \\
\hline 15:0 & - & $0.42 \pm 0.03^{b}$ & - & $0.66 \pm 0.04^{a}$ & - & - & - & - & - & - & - & - \\
\hline $16: 0$ & $18.87 \pm 0.56^{a}$ & $16 . .54 \pm 0.24 b$ & $15.14 \pm 0.62^{b c}$ & $14.58 \pm 0.07 \mathrm{~cd}$ & $13.88 \pm 0.36^{\mathrm{cd}}$ & $11.85 \pm 0.09 c$ & $14.99 \pm 0.29 \mathrm{bcd}$ & $14.52 \pm 0.64^{\mathrm{cd}}$ & $12.93 \pm 1.02^{\mathrm{ac}}$ & $13.97 \pm 0.28^{\mathrm{cd}}$ & $13.89 \pm 0.64^{\text {cd }}$ & $14.12 \pm 0.16^{c}$ \\
\hline $17: 0$ & - & $1.36 \pm 0.05^{\mathrm{ab}}$ & - & $0.60 \pm 0.02^{c}$ & $1.12 \pm 0.32^{b}$ & $1.48 \pm 0.03 a$ & - & - & $1.27 \pm 0.04^{\mathrm{ab}}$ & $1.49 \pm 0.02^{a}$ & - & $1.13 \pm 0.13^{c d}$ \\
\hline 18:0 & - & $3.40 \pm 0.03^{d}$ & $3.93 \pm 0.13^{\text {defg }}$ & $3.87 \pm 0.06^{\mathrm{dfg}}$ & $3.78 \pm 0.04^{d g}$ & $4.70 \pm 0.03^{\text {abde }}$ & $4.38 \pm 0.25^{\text {bdef }}$ & $5.59 \pm 0.38^{\mathrm{a}}$ & $4.74 \pm 0.74^{\mathrm{abd}}$ & $5.20 \pm 0.02^{\mathrm{abc}}$ & $5.22 \pm 0.06^{\mathrm{ab}}$ & $4.30 \pm 0.09 \mathrm{efg}$ \\
\hline $20: 0$ & - & $0.83 \pm 0.01$ & - & - & - & - & - & - & - & - & - & - \\
\hline $22: 0$ & - & $0.52 \pm 0.09$ & - & - & - & - & - & - & - & - & - & - \\
\hline $24: 0$ & - & $0.99 \pm 0.03^{a}$ & - & - & - & - & - & - & - & $1.25 \pm 0.39 \mathrm{a}$ & - & $0.96 \pm 0.08^{a}$ \\
\hline
\end{tabular}

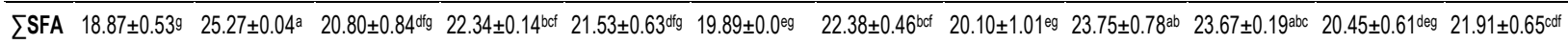
Values in the same line followes by different letters are significantly different $(P<0.05), n=3$, mean $\pm S D$

PUFA are synthesized by primary producers and then consumed and incorporated into the tissues of grazers and secondary consumers (Dalsgaard et al., 2003). In particular, the PUFA such as 20:4 n-6 (ARA: Arachidonic acid), EPA and DHA cannot be synthesized by most heterotrophs, but are essential components of membranes, and as such are termed essential fatty acids (EFA). The source of these EFA are of significant interest in aquatic food web studies and can provide fundamental information about plankton condition and trophodynamics. Furthermore, the relative quantities of marker fatty acids in consumers, including 22:6n-3, 20:5 n-3 (EPA), 18:1 n-9, and long chain monounsaturated fatty acids (MUFA), are often used as indicators of specific food sources (Falk-Petersen et al., 2000; Dalsgaard et al., 2003). For example: ratios 18:1 n-9/18:1 n-7, DHA/EPA and 16 carbon/18 carbon fatty acids $\left(\sum 16 \mathrm{C} / \sum 18 \mathrm{C}\right)$ are also useful when determining the relative contributions of animal prey or different phytoplankton groups (e.g. dinoflagellate versus diatom food) to consumer diets (Dalsgaard et al., 2003). $\sum$ n$3 / \sum n-6$ ratio represents an herbivory index (Sargent and Falk- 
Petersen, 1981), and the ratios 18:1 n-9/18:1 n-7 and DHA/EPA are carnivory indixes (Cripps and Atkinson, 2000; Dalsgaard et al., 2003). $\sum$ PUFA/ $\Sigma$ SFA ratio can be a useful freshness (Derieux et al., 1998) or diatom index for suspended particulates (Claustre et al., 1989), or a potential carnivory index in some consumers (Cripps and Atkinson, 2000). In this manner, fatty acid profiles can inform us about the predominant food and feeding plasticity of herbivorous and omnivorous zooplankton. Alterations in fatty acids occur from one trophic level to the next, but valuable dietary information can be retained despite these metabolic modifications (Dalsgaard et al., 2003). In the study, DHA/EPA changed between 1.62-2.49 as carnivory index, and winter is seen that it is the period with highest values with an average of 2.29 (Table 2). When the fact that the total copepod abundance is at the peak level in winter $\left(2549 \mathrm{ind} / \mathrm{m}^{3}\right)$ is considered, it might be thought that the carnivory index of $S$. setosa being high may stem from the copepods it feds on. As a result of the statistical analyses, it was observed that the EPA level (whose increase decreases carnivore index) was at the lowest level in $S$. setosa in autumn $(9.15 \%)$, which is different from the other seasons $(p<0.05) .18: 1 n-7$ is not considered as the dominant MUFA during the sampling period in $S$. setosa. 18:1 n-9 is considered as the most dominant MUFA (8.57-12.20) in S. setosa (Table 3). However, unlike DHA/EPA, 18:1 n-9/18:1 n-7 ratio had its lowest average value (8) in winter, and had its highest average value (11) in summer.

However, the fact that the 18:1 n-7, which will decrease the carnivore index, was not detected in the fatty acids during the sampling period. 18:1 n-9 being among the most important fatty acids of $S$. setosa may be shown as the proof that although $S$. setosa does not always show a predation on copepods, it feeds in a carnivorous manner. In addition, the $\sum n-3 / \sum n-6$ ratio, which is the herbivore index, was determined in spring and autumn at the highest levels.

Table 2. PUFA composition of $S$. setosa during the sampling period (\% determined total FAME)

\begin{tabular}{|c|c|c|c|c|c|c|c|c|c|c|c|c|}
\hline FA & March & April & May & June & July & August & September & October & November & December & January & February \\
\hline $18: 2 n 6 c$ & - & $1.92 \pm 0.04^{d}$ & $2.41 \pm 0.02^{\mathrm{bc}}$ & $2.19 \pm 0.06^{c d}$ & $2.25 \pm 0.0 g^{c d}$ & $3.69 \pm 0.26^{\mathrm{a}}$ & $2.23 \pm 0.02^{\mathrm{cd}}$ & $3.48 \pm 0.20^{\mathrm{a}}$ & $2.28 \pm 0.44^{c d}$ & $2.10 \pm 0.088^{c d}$ & $2.82 \pm 0.24^{b}$ & $1.42 \pm 0.02^{\mathrm{e}}$ \\
\hline $18: 3 n 3 c$ & - & $1.70 \pm 0.02^{\mathrm{bc}}$ & $1.37 \pm 0.08$ cef & $1.13 \pm 0.04^{\text {efg }}$ & $0.96 \pm 0.019$ & $2.44 \pm 0.42^{\mathrm{a}}$ & - & - & $1.12 \pm 0.012^{\mathrm{efg}}$ & $1.97 \pm 0.52^{b}$ & $1.44 \pm 0.33^{c e}$ & $1.05 \pm 0.02^{\mathrm{fg}}$ \\
\hline $20: 2 n 6$ & - & $2.51 \pm 0.04^{\mathrm{a}}$ & $1.40 \pm 0.01^{d}$ & - & - & - & - & - & - & $1.64 \pm 0.01^{b}$ & $2.15 \pm 0.05^{b}$ & $1.29 \pm 0.07^{d}$ \\
\hline $20: 3 n 6$ & - & $0.25 \pm 0.03^{c}$ & - & - & - & $2.77 \pm 0.33^{\mathrm{a}}$ & - & - & - & $0.70 \pm 0.03^{b}$ & - & - \\
\hline $20: 4 n 3$ & - & $1.79 \pm 0.01^{c}$ & $1.53 \pm 0.01 \mathrm{ce}$ & - & - & $2.49 \pm 0.16 d$ & - & $3.29 \pm 0.01 \mathrm{e}$ & - & $1.41 \pm 0.13^{\mathrm{de}}$ & $1.76 \pm 0.24^{c}$ & $1.13 \pm 0.03^{d}$ \\
\hline $20: 4 n 6$ & - & $0.53 \pm 0.01^{d}$ & - & $0.75 \pm 0.02^{b}$ & $0.88 \pm 0.02^{b}$ & - & - & - & $1.10 \pm 0.02^{\mathrm{a}}$ & $0.77 \pm 0.02^{c}$ & - & $0.58 \pm 0.04^{d}$ \\
\hline $22: 2$ & - & $0.51 \pm 0.01^{\mathrm{a}}$ & - & - & - & $1.57 \pm 0.04^{a}$ & - & - & - & - & - & - \\
\hline 20:5n3(EPA) & $19.26 \pm 0.34^{a}$ & $16.45 \pm 0.12^{\mathrm{de}}$ & $16.90 \pm 0.30^{a}$ & $17.92 \pm 0.14^{\mathrm{abc}}$ & $17.42 \pm 0.17^{\mathrm{bcd}}$ & $15.62 \pm 0.39$ ef & $18.68 \pm 0.33^{\mathrm{ab}}$ & $16.82 \pm 0.69$ cde & $14.43 \pm 0.43^{f}$ & $15.98 \pm 0.08^{\mathrm{de}}$ & $16.99 \pm 0.40$ cde & $18.75 \pm 0.27^{\mathrm{ab}}$ \\
\hline $22: 5 n 3$ & - & $0.57 \pm 0.01^{b}$ & - & - & - & - & - & - & - & $0.68 \pm 0.05^{\mathrm{a}}$ & - & - \\
\hline 22:6n3(DHA) & $39.24 \pm 1.23^{a}$ & $26.61 \pm 0.18^{d}$ & $32.45 \pm 0.84^{b}$ & $34.99 \pm 0.28 \mathrm{ab}$ & $35.41 \pm 0.86^{\mathrm{ab}}$ & $32.39 \pm 0.47^{b}$ & $37.75 \pm 0.91^{a c}$ & $39.30 \pm 1.34^{a}$ & $32.38 \pm 2.52^{b}$ & $38.20 \pm 0.41^{a c}$ & $39.94 \pm 1.32^{\mathrm{a}}$ & $37.23 \pm 0.15^{a c}$ \\
\hline$\sum$ PUFA & $58.49 \pm 1.57^{d c}$ & $52.84 \pm 0.29^{\mathrm{eff}}$ & $56.06 \pm 1.22^{d e}$ & $56.98 \pm 0.36^{d}$ & $56.91 \pm 0.93^{d}$ & $60.97 \pm 0.52^{b c}$ & $58.65 \pm 0.57 \mathrm{dc}$ & $63.41 \pm 1.57^{\mathrm{ab}}$ & $51.31 \pm 2.55^{f}$ & $63.47 \pm 0.48^{\mathrm{ab}}$ & $65.45 \pm 1.12^{\mathrm{a}}$ & $63.01 \pm 0.34^{a b}$ \\
\hline DHA/EPA & $2.04 \pm 0.03^{c d}$ & $1.62 \pm 0.01 \mathrm{e}$ & $1.92 \pm 0.04^{d}$ & $1.95 \pm 0.01^{d}$ & $2.03 \pm 0.03^{\mathrm{cd}}$ & $2.07 \pm 0.03^{c d}$ & $2.02 \pm 0.06^{\mathrm{cd}}$ & $2.34 \pm 0.02^{\mathrm{ab}}$ & $2.24 \pm 0.10^{b c}$ & $2.39 \pm 0.01^{\mathrm{ab}}$ & $2.49 \pm 0.11^{\mathrm{a}}$ & $1.99 \pm 0.02^{d}$ \\
\hline
\end{tabular}

Table 3. MUFA composition of $S$. setosa during the sampling period (\% determined total FAME)

\begin{tabular}{|c|c|c|c|c|c|c|c|c|c|c|c|c|}
\hline FA & March & April & May & June & July & August & September & October & November & December & January & February \\
\hline $15: 1$ & - & - & - & - & - & - & - & - & - & - & - & $1.16 \pm 0.05$ \\
\hline $16: 1 n 7$ & $10.74 \pm 0.63^{a}$ & $7.35 \pm 0.17 \mathrm{bc}$ & $6.28 \pm 0.01^{\mathrm{fg}}$ & $5.51 \pm 0.09^{\mathrm{deg}}$ & $6.61 \pm 0.20$ cf & $6.23 \pm 0.29 f g$ & $6.11 \pm 1.00^{f g}$ & $7.73 \pm 0.64 b$ & $5.19 \pm 0.01 \mathrm{de}$ & $4.97 \pm 0.25^{\mathrm{e}}$ & $5.09 \pm 0.08 \mathrm{e}$ & $6.33 \pm 0.18^{f g}$ \\
\hline $18: 1 n 7$ & - & $3.51 \pm 0.07^{a}$ & $2.86 \pm 0.12^{b}$ & - & - & - & - & - & - & $1.83 \pm 0.02^{c}$ & $1.67 \pm 0.04^{c}$ & $1.61 \pm 0.08^{c}$ \\
\hline $18: 1 n 9 t$ & - & - & $1.04 \pm 1.02^{c}$ & $1.02 \pm 0.01^{c}$ & $1.07 \pm 0.01 c$ & - & - & - & $1.61 \pm 0.05^{a}$ & - & - & $1.23 \pm 0.08^{b}$ \\
\hline $18: \ln 9 c$ & $11.90 \pm 0.42^{\mathrm{a}}$ & $9.98 \pm 0.15^{b c}$ & $9.30 \pm 0.36^{c}$ & $10.90 \pm 0.58^{a b}$ & $11.13 \pm 0.5^{\mathrm{ab}}$ & $8.57 \pm 0.0 \mathrm{gcd}^{\mathrm{cd}}$ & $10.93 \pm 0.22^{a b}$ & $9.28 \pm 0.24 c$ & $7.67 \pm 1.37^{d}$ & $7.30 \pm 0.27^{d}$ & $8.77 \pm 0.57^{\mathrm{cd}}$ & $7.36 \pm 0.03^{d}$ \\
\hline $20: 1 \mathrm{n} 9$ & - & $0.43 \pm 0.01^{d}$ & $1.21 \pm 0.01 \mathrm{bc}$ & $1.25 \pm 0.07^{b}$ & $0.90 \pm 0.01^{\mathrm{c}}$ & - & $1.94 \pm 0.06^{a}$ & - & $1.79 \pm 0.13^{\mathrm{a}}$ & - & - & - \\
\hline $20: 1 n X$ & - & - & $2.45 \pm 0.03^{b}$ & $1.39 \pm 0.06^{c}$ & $0.95 \pm 0.01 d$ & - & - & - & $3.18 \pm 0.12^{a}$ & - & - & - \\
\hline $22: 1 n 9$ & - & $0.63 \pm 0.04 \mathrm{~cd}$ & - & $0.62 \pm 0.02^{\mathrm{cd}}$ & $0.91 \pm 0.02^{c}$ & $2.64 \pm 0.19 b$ & - & - & $6.62 \pm 0.19 \mathrm{a}$ & $0.73 \pm 0.04 \mathrm{~cd}$ & - & - \\
\hline $24: 1$ & - & - & - & - & - & $1.70 \pm 0.16^{a}$ & - & - & - & - & - & - \\
\hline
\end{tabular}

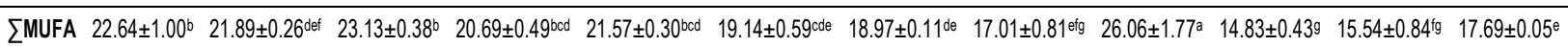
Values in the same line followes by different letters are significantly different $(P<0.05), n=3$, mean $\pm S D$

Seas and oceans that are located in temperate zones are characterized with two seasonal peaks, which are spring and autumn, in terms of phytoplankton concentrations (Lalli and Parsons, 2004). Chlorophyll-a (Chl-a) concentration decreases in winter in the coastal areas of Trabzon in
Southeastern Black Sea Region, and increases in autumn. Two main peaks are observed, which are late winter-early spring, and early summer (mostly June) (Alkan et al., 2013). Şen Özdemir et al. (2017) indicated that average chl-a concentration increased in spring (May-late spring) and winter 
(December-early winter). Chl-a is used as the indicator of the phytoplankton abundance. This shows that the herbivory index being high in $S$. setosa in this period stems from the herbivorous nutrients that are consumed due to high chl-a levels. In addition, it is clear that the reproduction cycles in chaetognaths are synchronized with the intense energy input that occurs with the spring phytoplankton blooms (Choe et al., 2003).

As a conclusion, we may say that although there is no direct relation between the copepod abundance and the fatty acids of $S$. setosa, it has an indirect effect. As a result, we can say that copepod abundance and $\mathrm{S}$. setosa have an indirect effect, although there is no direct relationship between fatty acids. This indirect effect can be defined as contributing to the higher trophic levels, especially when copepods are abundant, S. setosa receives herbivory index fatty acids by feeding on copepods. Choe et al. (2003) indicated that the temporal variation in the abundance of adult copepods was highly correlated with the biochemical levels of chaetognath

\section{REFERENCES}

Ackman, R.G., Linke, B.A. \& Hingley, J. (1974). Some details of fatty acids and alcohols in the lipids of North Atlantic Copepods, ournal of the Fisheries Research Board of Canada, 31, 1812-1818.

Alkan, A., Zengin, B., Serdar, S. \& Oğuz, T. (2013). Long-Term (2001-2011) Temperature, salinity and Chlorophyll-a variations at a Southeastern Coastal site of the Black Sea. Turkish Journal of Fisheries and Aquatic Sciences, 13, 57-68. DOI: 10.4194/1303-2712-V143_1_08

Arts, M.T., Brett, M.T. \& Kainz, M.J. (2009). Lipids in Aquatic Ecosystems, Dordrecht, The Netherlands: Springer. DOI: 0.1007/978-0-387-89366-2

Baier, C. \& Purcell, J.E. (1997). Trophic interactions of chaetognaths, larval fish, and zooplankton in the South Atlantic Bight. Marine Ecology Progress Series, 146, 43-53.

Beşiktepe, S. \& Ünsal, M. (2000). Population structure, vertical distribution and diel migration of Sagitta setosa (Chaetognatha) in the south-western part of the Black Sea. Journal of Plankton Research, 22, 669-683. DOI: 10.1093/plankt/22.4.669

Choe, N., Deibel, D., Thompson, R.J., Lee, S.H. \& Bushell, V.K. (2003). Seasonal variation in the biochemical composition of the chaetognath Parasagitta elegans from the hyperbenthic zone of Conception Bay, Newfoundland. Marine Ecology Progress Series, 251, 191-200.

Claustre, H., Marty, J.C. \& Cassani, L. (1989). Intraspecific differences in the biochemical composition of a diatom during a spring bloom in Villefranche-sur-mer Bay, Mediterranean Sea. Journal Experimental Marine Biology and Ecology, 129, 17-32.

DOI:10.1016/0022-0981(89)90060-9

Cook, H.W. (1996). Fatty acid desaturation and chain elongation in eukaryotes. In D.E. Vance and J.E. Vance (Eds.), Biochemistry of Lipids and Membranes (pp 129-152). Amsterdam: Elsevier.

Cripps, G.C. \& Atkinson, A. (2000). Fatty acid composition as an indicator of carnivory in Antarctic krill, Euphausia superba. Canadian Journal of Fisheries and Aquatic Sciences, 57, 31-37. DOI: 10.1139/f00-167

Dalsgaard, J., St John, M., Kattner, G., Muller-Navarra, D. \& Hagen, W. (2003). Fatty acid trophic markers in the pelagic marine environment. Advances in Marine Biology, 46, 225-340

Duró, A. \& Saiz, E. (2000). Distribution and trophic ecology of chaetognaths in the western Mediterranean in relation to an inshore-offshore gradient. Journal of Plankton Research, 22, 339-361. DOI: $10.1093 /$ plankt/22.2.339 species (Parasagitta elegans). In aquatic food webs, FAs are synthesized by phytoplankton and bacteria, and then transferred via zooplankton to higher trophic levels (Parrish, 2009). Additionally, Choe et al. (2003) suggested that that there was tight coupling of energy transfer from primary producers to carnivorous hyperbenthic chaetognaths following the spring phytoplankton bloom in Newfoundland coastal waters. Therefore, if we consider the food chain as a whole, not only copepods, but also the abundance changes of the main nutrient sources (phytoplankton) of the copepods can be said to have an effect on the fatty acid composition of $S$. setosa.

\section{ACKNOWLEDGEMENTS}

We thank Research Assistant Ümit DOKUZPARMAK and the crew of KTU YAKAMOZ for help in collection of the samples, and Prof. Dr. Ökkeş YILMAZ for his help with GC analyses. This work was a part of PhD study supported by KTU BAP, 2010.117.001.9.

Derieux, S., Fillaux, J. \& Saliot, A. (1998). Lipid class and fatty acid distributions in particulate and dissolved fractions in the north Adriatic Sea. Organic Geochemistry, 29, 1609-1621.

DOI: 10.1016/S0146-6380(98)00089-8

Falk-Petersen, S., Hagen, W., Kattner, G., Clarke, A. \& Sargent, J.R. (2000). Lipids, trophic relationships, and biodiversity in Arctic and Antarctic krill. Canadian Journal of Fisheries and Aquatic Sciences, 57, 178-191. DOI: 10.1139/f00-194

Feigenbaum, D.L. \& Maris, R.C. (1984). Feeding in the Chaetognatha. Oceanography and Marine Biology - An Annual Review, 22, 343-392.

Feigenbaum, D.L. (1991). Food and feeding behaviour. In Q. Bone, H. Kapp, A.C. Pierrot-Bults (Eds), The Biology of Chaetognaths (pp 45-54) New York: Oxford University Press.

Folch, J., Lees, M. \& Sloane-Stanley, G.H. (1957). A Simple Method for the Isolation and Purification of Total Lipides from Animal Tissues. The Journal of Biological Chemistry, 226, 497-509.

Harris, R.P., Wiebe, P.H., Lenz, J., Skjoldal, H.R. \& Huntley, M. (2000). ICES Zooplankton Methodology Manual. London, UK: Academic Press.

Harvey, H.R., Eglinton, G., O'Hara, S.C.M. \& Corner, E.D.S (1987). Biotransformation and assimilation of dietary lipids by Calanus feeding on a dinoflagellate. Geochimica et Cosmochimica Acta, 51, 3031-3040

Johnson, W.S. \& Allen, D.M. (2005). Zooplankton of the Atlantic and Gulf coasts: A Guide to Their Identification and Ecology. Baltimore, MD, USA: Johns Hopkins University Press.

Kates, M. (1986). Techniques of lipidology: isolation, analysis, and identification of lipids. 2nd Edition, Amsterdam: New York: Elsevier Science Pub Co, 3(2), 464.

Kovalev, A., Beşiktepe, S., Zagorodnyaya, Yu. A. \& Kideys, A.E. (1998). Mediterranization of the Black Sea zooplankton is continuing. In L. Ivanov, T. Oguz (Eds), NATO TU-Black Sea Project: Ecosystem Modeling as a Management Tool for the Black Sea, Symposium on Scientific Results ( pp 21-234). Kluwer Academic Publishers.

Lalli, C.M. \& Parsons, T.R. (2004). Biological Oceanography an Introduction (pp 314). University of British Columbia, Vancouver, Canada.

Lee, R.F., Hirota, J. \& Barnett, A.M. (1971). Distribution and importance of wax esters in marine copepods and in other zooplankton. Deep- Sea Research, 18, 1147-1165 
Litzow, M.A., Bailey, K.M., Prahl, F.G. \& Heintz, R. (2006). Climate regime shifts and reorganization of fish communities: the essential fatty acid limitation hypothesis. Marine Ecology Progress Series, 315, 1-11.

Mauchline, J, Blaxter, J.H.S., Southward, A.J. \& Tyler, P.A. (1998). The Biology of Calanoid Copepods. Advances in Marine Biology, Vol. 33. San Diego, CA, USA: Academic Press.

Morris, R.J. (1971). Comparison of the composition of oceanic copepods from different depths. Comparative Biochemistry and Physiology, $40 \mathrm{~B}$, 275-281.

Müller-Navarra, D.C. (1995). Biochemical versus mineral limitation in Daphnia. The American Society of Limnology and Oceanography, 40, 1209-1214.

Müller-Navarra, D.C, Brett, M.T., Liston, A. \& Goldman, C.R. (2000). A highlyunsaturated fatty acid predicts biomass transfer between primary producers and consumers. Nature, 403, 74-77. DOI: 10.1038/47469.

Niermann, U. \& Greve, W. (1997). Distribution and fluctuation of dominant zooplankton species in the southern Black Sea in comparison to the North Sea and Baltic Sea. In Proceedings of the NATO Advanced Research Workshop on Sensitivity of North Sea, Baltic Sea and Black Sea to Anthropogenic and Climatic Changes (pp 65-77), Varna, Bulgaria.

Niermann, U., Bingel, F., Ergun, G. \& Greve, W. (1998). Fluctuation of dominant mesoplankton species in the Black Sea, North Sea and the Baltic Sea. Is a general trend recognisable? Turkish Journal of Zoology, 22, 63-82.

Øresland, V. (1983). Abundance, breeding and temporal size distribution of the chaetognath Sagitta setosa in the Kattegat. Journal of Plankton Research, 5, 425-439.

Øresland, V. (1985). Temporal size and maturity-stage distribution of Sagitta elegans and occurrence of other chaetognath species in Gullmarsfjorden, Sweden. Sarsia, 70, 95-101.

Øresland, V. (1987). Feeding of the chaetognaths Sagitta elegans and S. setosa at different seasons in Gullmarsfjorden, Sweden. Marine Ecology Progress Series, 39, 69-79.

Öztürk, S. (2002). Time-Dependent Distribution and Population structure of Sagitta Setosa in Sürmene Bay, MSc Thesis, KTU The Graduate of Naturel and Applied Sciences, Turkey, Trabzon, 43 pp. (in Turkish).

Parrish, C.C. (2009). Essential fatty acids in aquatic food webs. In M. T. Arts, M. T. Brett, M. Kainz (Eds). Lipids in aquatic ecosystems (pp 306-326). New York, USA: Springer.

Prahl, F.G., Eglinton, G., Corner, E.D.S, MO'hara, S.C. \& Forsberg, T.E.V. (1984). Changes in plant lipids abundance passage through the gut of Calanus. Journal of Marine Biology Association UK, 64(3), 17-334.
Pond, C.M. (1998). The Fats of Life. Cambridge University Press, Cambridge, UK

Ravet, J.L., Brett, M.T. \& Müller-Navarra, D.C. (2003). A test of the role of polyunsaturated fatty acids in phytoplankton food quality for Daphnia using liposome supplementation. Limnology and Oceanography, 48, 1938-1947. DOI: 10.4319/lo.2003.48.5.1938

Reeve, M.R. (1980). Comparative experimental studies on the feeding of chaetognaths and ctenophores. Journal of Plankton Research, 2, 381393.

Rustan, A.C. \& Drevon, C.A. (2005). Fatty Acids: Structures and Properties. Encyclopedia of Life Sciences 1-7. DOI: 10.1038/npg.els.0003894

Sargent, J.R. \& Falk-Petersen S. (1981). Ecological investigations on the zooplankton community in Balsfjorden, northern Norway: lipids and fatty acids in Meganyctiphanes norvegica, Thysanoessa raschi and $T$. inermis abundance mid-winter. Marine Biology, 62, 131-137.

Sargent, J.R. \& Falk-Petersen, S. (1988). The lipid chemistry of Calanoid Copepods. Hydrobiologia, 167(1), 101-114.

Sen Ozdemir, N., Feyzioglu, A.M., Caf, F. \& Yildiz, I. (2017). Seasonal changes in abundance, lipid and fatty acid composition of Calanus euxinus in the South-eastern Black Sea. Indian Journal of Fisheries, 64(3): 55-66. DOI:10.21077/ijf.2017.64.3.62172-09

Şen Özdemir, N. (2013). Zooplankton of Eastern Black Sea (Trabzon Coastline) and Seasonal Changes in Fatty Acid Composition of Zoopolankton, Phd Thesis, KTU The Graduate of Naturel and Applied Sciences, Turkey (in Turkish).

Ünal, E. (2002). Seasonality of zooplankton in the Southern Black Sea and genetics of Kopepot Calanus euxinus, MSc Thesis, ODTÜ, Marine Sciences Institute, Ankara, Turkey (in Turkish)

Veloza, A.J., Chu, F.E. \& Tang, K.W. (2006). Trophic modification of essential fatty acids by heterotrophic protists and its effects on the fatty acid composition of the copepod Acartia tonsa. Marine Biology, 148, 779-788. DOI: 10.1007/s00227-005-0123-1

Vinogradov, M.Ye, Musayeva, E.I. \& Semenova, T.N. (1990). Factors determining the position of the lower layer of mesoplankton concentration in the Black Sea. Oceanology, 30, 217-224.

Vinogradov, M.Ye, Sapozhnikov, V.V. \& Shushkina, E.A. (1992) The Black Sea Ecosystem (112 pp). Moscow, Russia: Nauka Dumka.

Yıldız, İ. \& Feyzioğlu, A.M. (2014). Biological Diversity and seasonal variation of mesozooplankton in the southeastern Black Sea coastal ecosystem. Turkish Journal of Zoology, 38, 179-10. DOI:10.3906/zoo-1304-32

Zenkevitch, L. (1963). Biology of the Seas of the USSR. George Allen and Unwin Ltd, London, pp. 403-426. 